\title{
BSA Involvement Score 2
}

National Cancer Institute

\section{Source}

National Cancer Institute. BSA Involvement Score 2. NCI Thesaurus. Code C131037.

$19-50 \%$ of body surface area involved. 